\title{
On the award of TMS Honorary Membership, 26 November 2005 \\ Professor John Murray - an appreciation
}

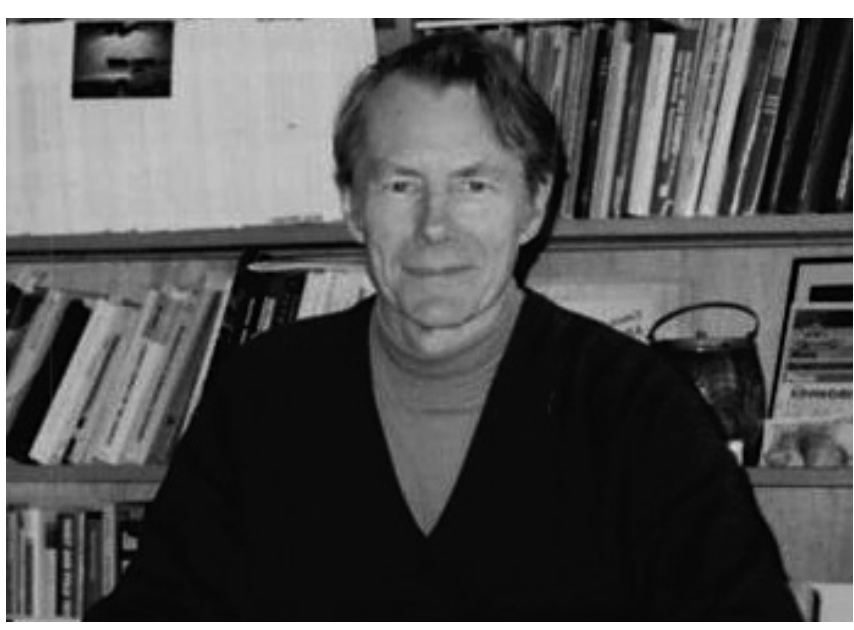

Contrary to popular belief, Professor John Murray and Sir John Murray (of Challenger fame) are not one and the same person. To begin with, their careers are separated by almost a century, but our Professor John Murray (B.Sc., ARCS, Ph.D., DIC, $\mathrm{D} . \mathrm{Sc})$ is hardly less renowned in today's world of micropalaeontology, especially with regards to ecological studies of the foraminifera.

John William Murray was born in London in 1937. Most of his childhood was however spent in Bury (now Greater Manchester), having been evacuated in WW2, before he moved back to Worthing, Sussex, when he was 16. As a child he had been seriously interested in microscopy and geology, and therefore it was not surprising that when he went up to university, he chose to read Pure Geology at Imperial College, University of London, in 1956. There, someone showed him some foraminifera in a First Year practical and he hasn't been able to keep away from them since! Not only did he get a First, but he won several prizes (the Murchison Medal, the Watts Medal and the Clement Le Neve Foster Prize) as well. On graduation he was offered the chance to undertake a Ph.D. in micropalaeontology, under David Carter. He chose to study the ecology of Recent foraminifera, which for the time was highly unusual. The result, a seasonal study of the living foraminifera of a small estuary (Christchurch Harbour, now in Dorset) was a seminal one. He was even kind enough, subsequently, to lend one of us (JEW) his original samples to work up the ostracods, as part of my Ph.D.

In 1961 he obtained a postdoc at the Marine Laboratory, Plymouth, carrying out experiments on living foraminifera and studying the ecology of a traverse from the Tamar Estuary. The need to get a 'proper job', following his marriage, however, took him to Bristol as a Lecturer in 1962, where he stayed until 1975. Highlights of his Bristolian days, were: expeditions to the Persian/Arabian Gulf in 1965 and again in 1969, where he sampled the lagoons and shallow shelf (and subsequently published extensively); a short 'John Murray Travelling Studentship' (from the Royal Society of London) to Woods Hole Oceanographic Institution (named after Sir John Murray, but they could not but give it to him, could they, with a name like that?); and a project, initially with Professor Whittard, to map the sea-floor of the English Channel. Bristol was also one of the first UK universities to buy a scanning electron microscope, and John, true to form, was not slow in persuading the Zoology Department to let him use it. The result was his highly acclaimed Atlas of British Recent Foraminiferids (1971).

In 1975 John moved to the University of Exeter, to be Professor of Geology and Head of Department. Unfortunately, he couldn't save its closure following the controversial reorganisation of Earth Sciences in British universities in 1989. Then on to Southampton to become Professor of Geology, at what is now the School of Ocean and Earth Sciences at the National Oceanographic Centre - in a fine new site by the city's rejuvenated dockland. There, he instituted and for 6 years, ran a M.Sc. course in Micropalaeontology, amongst his other onerous teaching duties.

One of us (EA) remembers first meeting him in the late 1980s. She, heavily pregnant at the time, was immediately dragged out onto some particularly sticky and treacherous mudflats to look for his 'dear forams'. Thus began a particular fine collaboration which was to lead to many joint-papers, including a baseline study of shallow water foraminifera from southern Scandinavia and many other ecological studies.

John formally retired in late 2003, but carries on his research regardless. Over a career spanning 40 years he has published 9 books and nigh on 150 papers in refereed scientific journals. He has (from his own estimates) supervised 24 Ph.D. students and taught several thousand undergraduates. He also acted as External Examiner for many years for the M.Sc. in Micropalaeontology degrees at University College, London and the University of Wales, Aberystwyth.

John's contribution to UK learned societies is also noteworthy. He has been President of the Palaeontological Association, Editor of Palaeontology, Honorary Secretary of the Geological Society of London, and served on the Earth Resource Committee, of the Royal Society of London.

In 2001 he received the prestigious Joseph A. Cushman Award for Foraminiferal Research, perhaps his most pleasing (and International) accolade, to date.

To summarise his micropalaeontological career in a nutshell? In short, John Murray has made an overwhelming contribution to our understanding of benthonic foraminiferal ecology. His scientific production is impressive and covers most environmental settings from near-Equatorial (Persian/Arabian Gulf) to polar (Antarctic) habitats. It also includes papers on taphonomy, stratigraphy, and pre-Quaternary assemblages. He 
has co-edited (two editions) of the Stratigraphic Atlas of Fossil Foraminifera and with his third book (since 1973) on benthonic foraminiferal ecology - Ecology and Application of Benthic Foraminifera (Cambridge University Press) - which is due to be published in September 2006, he will have encouraged and aided, more than almost any other, the education of generations of micropalaeontologists throughout the world. While many workers take on a primarily administrative role as they become more senior and leave most of the scientific work to students and post-doctorates, John enjoys his scientific work so much that he still preferred to do most of it himself. Many of us have problems meeting deadlines when submitting ordinary sized manuscripts to conference volumes, etc. John has submitted his MS for his latest ecology book, including an impressive number of web appendix tables ... before the deadline!

What of his hobbies? What we can think of, apart from foraminifera, are watercolour painting (and he's very good at it), carpentry, gardening, reading and walking. If one wanted to be flippant, one could add collecting ostracods ... and there lies a story! John is the part author of the discovery of Terristricythere in Britain. Whilst collecting high salt-marsh foraminifera in the Hamble estuary, he (aided and abetted by EA) discovered in oak-leaf litter this remarkable (semi-)terrestrial ostracod (Horne et al., 2004). No-one else would have bothered to look in such an unlikely ecological niche.

To those who know him he is great fun, with a wicked sense of humour. To those who don't, he may seem a rather reserved gentleman. We can, however, vouch for his friendship, his enthusiasm, and his ability as a teacher and mentor.

Last year the Committee felt that recognition from the TMS was long overdue. He had been Secretary of the Foraminifera Group back in 1972-1974, Chairman of the Society (1978-1980) and a highly successful Editor of the Journal of Micropalaeontology (1994-1997). At the 2005 AGM the Chairman, Professor David Siveter, was pleased to present Honorary Membership to John Murray ... 'for his lasting contribution to research and education in the field of micropalaeontology and for his support and service to the Society in many capacities'.

\section{REFERENCES}

Horne, D.J., Smith, R.J., Whittaker, J.E. \& Murray, J.W. 2004. The first British record and a new species of the superfamily Terrestricytheroidea (Crustacea, Ostracoda): morphology, ontogeny, lifestyle and phylogeny. Zoological Journal of the Linnean Society, 142: 253-288.

John E. Whittaker Department of Palaeontology, The Natural History Museum, Cromwell Road, London SW7 5BD

(e-mail: j.whittaker@nhm.ac.uk)

Elisabeth Alve

Department of Geosciences, University of Oslo, P.O. Box 1047 Blindern, 0316 Oslo Norway

(e-mail: elisabeth.alve@geo.uio.no) 